University of Montana

ScholarWorks at University of Montana

Global Humanities and Religions Faculty

Publications

Global Humanities and Religions

Spring 2000

\title{
Mariological Memory in The Winter's Tale and Henry VIII
}

Ruth Vanita

University of Montana - Missoula, ruth.vanita@umontana.edu

Follow this and additional works at: https://scholarworks.umt.edu/libstudies_pubs

Part of the Feminist, Gender, and Sexuality Studies Commons

Let us know how access to this document benefits you.

\section{Recommended Citation}

Vanita, Ruth, "Mariological Memory in The Winter's Tale and Henry VIII" (2000). Global Humanities and Religions Faculty Publications. 4.

https://scholarworks.umt.edu/libstudies_pubs/4

This Article is brought to you for free and open access by the Global Humanities and Religions at ScholarWorks at University of Montana. It has been accepted for inclusion in Global Humanities and Religions Faculty Publications by an authorized administrator of ScholarWorks at University of Montana. For more information, please contact scholarworks@mso.umt.edu. 


\section{PROJECT MUSE}

\section{Mariological Memory in The Winter's Tale and Henry VIII}

Ruth Vanita

SEL Studies in English Literature 1500-1900, Volume 40, Number 2, Spring 2000, pp. 311-337 (Article)

Published by The Johns Hopkins University Press DOI: 10.1353/sel.2000.0021

$\Rightarrow$ For additional information about this article http://muse.jhu.edu/journals/sel/summary/v040/40.2vanita.html 


\title{
Mariological Memory in The Winter's Tale and Henry VIII
}

\author{
RUTH VANITA
}

The Winter's Tale and Henry VIII are built on a paradox-their women protagonists acquire increased moral authority even while they are being demoted and persecuted. The structure of these plays supports this empowering through a series of spectacles of female fictive kinship. While male kinship, especially patrilineage, is central to the construction of Shakespeare's histories and tragedies, female fictive lineage is crucial to the vision of these two plays. Henry VIII and The Winter's Tale visually and verbally construct succession through a series of mutually sympathetic female figures who are not necessarily biologically related: Hermione/ Paulina/Perdita; Katherine/Anne/Elizabeth. Shakespeare draws on a range of sources to represent women as inheriting intangible but important strengths from one another. This paper will explore how two of these sources-Marian mythology and the historical events of Henry VIII's relations with his wives and children-function in rich interplay with one another in both plays. The plays appeal to the audience's collective memory of both sources. Elements of Mariology critique male-female relations and suggest visionary resolutions which resonate with the medieval past and look forward to an imagined Utopian future. ${ }^{1}$

I argue that these plays mourn the loss of those popular elements of the old religion that imaginatively empowered the powerless, especially women, and that combated the power of the patriarchal family through valorization of fictive kinship and same-sex community. The plays also celebrate these elements of the common culture and reinscribe them into theatrical performances that in many ways replace the cultural power of

Ruth Vanita is associate professor of liberal studies at the University of Montana and was previously Reader, English Department, Delhi University. She is the author of Sappho and the Virgin Mary: Same-Sex Love and the English Literary Imagination (1996) and coauthor of Same-Sex Love in India: Readings from Literature and History (2000). 
communal church ritual and practice. I shall first give a brief account of some of these elements in Mariology and the saints' cults and then go on to a reading of patterns of fictive female kinship in the two plays.

The cults of the Virgin and of the female saints have been viewed with ambiguity by many twentieth-century feminists. Marina Warner's view of the Virgin as a patriarchal construct whose inimitability functions to castigate real women has tended to dominate modern feminist discourse on the Virgin. ${ }^{2}$ More recently, however, several commentators have argued that this view of the Virgin's cult is too literalist and underestimates the medieval ability to think metaphorically. Although Mary's feat of producing a child while remaining physically a virgin is literally inimitable, it is metaphorically imitable, and Mary was constantly invoked as a model both by women who produced works of art instead of children, as well as by nuns, female saints, and religious laywomen who saw their students, followers, or the world at large as their children. It is in this sense that Mary as model is central to the intellectual and spiritual all-female lineage that Christine de Pizan constructs in her City of Women. ${ }^{3}$ This kind of female lineage, transmitting a moral power that contrasts with and is ultimately perceived as greater than the male lineage of economic and political power, was an integral part of the Marian cults that the Protestant reformers vehemently attacked.

The cult of Mary was always grounded in popular devotion, which subscribed to such doctrines as the immaculate conception of the Virgin (that she, like Christ, was conceived without sin, as an idea in the mind of god, before the creation of the world), her Assumption into heaven, her queenship of heaven and her position as co-creatrix and co-redemptrix, centuries before they were declared as dogma by papal decree. ${ }^{4}$ Art depicted Mary as a student-learning at the knee of her mother Anne; a teacher-instructing the child Jesus and also instructing numerous male and female scholars; and a scholar-who appears in almost symbiotic relation with the book, who composes the Magnificat, and who presides over scholarly communities on earth and in heaven. This model was given material reality by the many nuns and female saints who refused or left marriage and family for convents, where they had access to education, scholastic debate, same-sex community, female bonding, and different types of power not available to wives and mothers. ${ }^{5}$ What to post-Freudians may appear desexualizing and therefore debilitating might have functioned as an empowering freedom from the burdens and dangers of compulsory heterosexuality in a society where contraception was not available and maternal mortality rates were alarmingly high. ${ }^{6}$ Mary can be read as one who opts out of heterosexual structures and acts as a model for others who wish to do so. ${ }^{7}$ 
Worshiped in her own right (in visual art, often without the baby) as protectress, mediatrix, and Queen of Heaven, Mary could be a model of freedom and autonomy. As a woman who protected victims, she was an attractive reversal of the stereotype of woman as victim. The popularity of her cult was grounded largely in her image as all-compassionate, willing, indeed especially eager, to forgive and protect the worst sinners. As many legends attest, she was perceived as particularly helpful to prostitutes, thieves, erring nuns, and other social outcasts. ${ }^{8}$ Crucial to this compassion was her own fully human status-having herself been once suspected by Joseph of sexual transgression, and having suffered poverty and pain, she could sympathize with other suffering sinners. She was the ultimate exemplar of the Judaeo-Christian tradition's privileging of the underdog, expressed in the paradox of the last being first.

Most important for my purposes, the medieval devotees of Mary did not worship her in isolation but in the context of a female lineage. The matrilineal holy kinship of Jesus consisted of his mother, grandmother Anne (whose cult was extremely popular in England), and great grandmother Emerentia, with the three often being depicted as a female trinity. ${ }^{9}$ Since Jesus' only human parent was a woman, his lineage was necessarily matrilineal. ${ }^{10}$ Mary's cousin Elizabeth and Mary's sisters and their children were also important figures in this lineage, which was frequently depicted as a garden of women and their children, with fathers either absent or present as shadowy background figures. Mary, her mother Anne who was barren before her miraculous conception of the Virgin, and Elizabeth, the Virgin's cousin who was an old woman when she conceived John the Baptist, were referred to as the three miraculous mothers. In some depictions of heaven, female saints from different historical periods, including several queens, were assimilated to this all-female community, so that the Virgin and her kin sat in an eternally timeless space with saints from various times and places. ${ }^{11}$ The women were often shown reading, writing, and playing different musical instruments, even while surrounded by their childrenthus, scholarship and the arts were represented as compatible with mothering.

In Shakespeare's early plays, women are disempowered by the absence of their natal kin or by the collaboration of their fathers with their accusing husbands. The often-noted absence of mothers in most of Shakespeare's plays may, as C. L. Barber has suggested, relate to the violent removal of Mary and the female saints from public life in early modern England, although not from collective memory and imagination. Barber argues that the removal of the benign mother left behind the threatening, witchlike mother. He is interested in a psychoanalytic reading of the male 
child's relation to father and mother in such a changing historical context: "the search for equivalents of the Holy Family of Christianity in the human family." 12 He does not, however, note that during this period, the patriarchal nuclear holy family progressively replaced the matrilineal holy kinship, and St. Joseph replaced Anne, while the consequences for women of the powerful mother's disappearance may have been even more difficult than for men. I am interested in those matrilineal, even Sapphic, elements of female bonding that were suggested in the cults of Mary and the female saints, and that are foregrounded in The Winter's Tale and Henry VIII.

Same-sex celibate community was often attacked by Protestant reformers for its supposedly unnatural character, flouting the normative heterosexual relationship ordered by God in the creation of Adam and Eve. Monks and nuns were frequently accused of homosexual as well as of heterosexual fornication. ${ }^{13}$ This kind of critique and suspicion of celibacy emerged from humanist valorization of companionate marriage that subordinated women within the family. Although Thomas More advocated women's education, he also enforced near-universal marriage for women in his Utopia. In Erasmus's dialogue "The Virgin Averse to Matrimony," a male suitor, dissuading a virgin from joining a convent, accuses nuns of "doing more than becomes maids to do" since "there are more among 'em that imitate Sappho in Manners, than are like her in Wit." 14

In this context, the remarkable plot of The Winter's Tale, which ensures that Hermione and Leontes spend the best part of their adult lives in celibacy, Hermione living in a women's community, posits a startling alternative to marriage. Unlike Thaisa in Pericles or Emilia in The Comedy of Errors, Hermione lives away from her husband by choice, not by force of circumstance. Several critics have expressed acute discomfort at the "unreal" or implausible nature of this choice, but for a woman to opt out of a marriage that has humiliated her is not necessarily implausible, and many medieval as well as Renaissance women made such choices. ${ }^{15}$

In her defense speech during her trial, which is also in a sense her opting-out speech, Hermione's most powerful argument is premised on a rhetorical "If," which, for her, represents not a hypothesis but a certainty. She knows it is futile to plead with Leontes-figuratively, she, like Isabella in Measure for Measure, Hero in Much Ado, Desdemona in Othello, or Cordelia in King Lear, is prejudged by the same male double standards which find her wanting. She appeals from these male standards to divine standards, and she is absolutely sure that divine powers are on the side of wronged women: 
But thus, if pow'rs divine

Behold our human actions (as they do), I doubt not then but innocence shall make

False accusation blush, and tyranny

Tremble at patience.

(III.ii.28-32) $)^{16}$

Although Hermione appeals to a male god (Apollo) and Shakespeare's audience too believed in a male God, both classical and Christian sacred traditions incorporated female presence, which the dramatist could draw on, to empower the maker of such a claim. The defense speech quoted above is addressed as much to spectators offstage as on-stage and assumes their assent to both premises-that divine powers exist and that they are opposed to all tyranny, including the tyranny of men over women.

As a queen, Hermione appears to be the most powerful woman in her society. But this power is extremely tenuous, as it depends on the whims of her husband. She bemoans the fact that although she is the daughter of a king, the wife of a king, and the mother of a prince, she can be so easily unqueened, thrown into prison, defamed, and threatened with death. That her unqueening and trial resonates with that of Henry VIII's wives has often been noticed. But another even more dramatic unqueening had occurred in England during that same time. Images of Mary, Queen of Heaven, had been removed or defaced in churches; her feasts and prayers to her were declared unlawful. Images of powerful female presence, such as those of Mary as Queen of Heaven, the Assumption, and the Immaculate Conception came under special attack by reformers intent on remasculinizing the idea of godhead. ${ }^{17}$ The replacement of the rood on church altarpieces by biblical texts and the royal arms also involved the removal of Mary and the saints, for the crucifix was invariably flanked by Mary and St. John. The disappearance of powerful female presence, Mary and the female saints, from churches, was accompanied by the disappearance of their counterparts in daily life, as nunneries and female communities were smashed, their inmates either forcibly converted and married or driven into exile. Unqueening, then, had multiple resonances for the Jacobean audience.

"[W]ithin the living memory of some of Shakespeare's audience" two of Henry's queens had been dethroned on the basis of sexual suspicion, followed by a paradoxical result-these queens' daughters, both at one time declared illegitimate, became queens in their own right as heirs. ${ }^{18}$ It was clear from Elizabeth's management of her career that a queen who came to the throne as daughter was far more powerful and also more secure than a queen-consort. Elizabeth's encouragement of the cult that glorified 
her in terms reminiscent of the Virgin Mary played on the idea of the power of the queen as daughter. ${ }^{19}$ Mary was queen as the eternal daughter of the ultimate king, God, and also, in Donne's words, as "thy maker's maker, and thy father's mother." ${ }^{20}$ But her cult represented her equally frequently as her mother's daughter; Philippa Berry has demonstrated that Elizabeth too relied on a community of women, her mother's kin, for support. ${ }^{21}$

Shakespeare radically alters his source, Robert Greene's Pandosto, by inventing Paulina and bringing Hermione back to life. His alterations result in the foregrounding of older female presence. The mother-daughter bonding, so evident at the end of this play, is cast in matrilineal terms. When mother meets daughter and no son is around, not Mary, mother of Jesus, but Anne, mother of Mary, is foregrounded.

Paulina is the centrally dynamic element in this lineage. At one level, she seems a fantastic figure-the completely fearless woman, so empowered by her moral authority that the ruler submits to her judgment, the older female ally who acts as Hermione's companion for sixteen years in a secluded life protected and hidden from male intervention. ${ }^{22}$ But the apparently fantastic has a base in history and cultural mythology. She is a rewriting of all those powerful older women (Anne, Elizabeth, the anonymous women in scenes of the Virgin's birth) who, in painting after painting, benignly preside over the youthful Mary's infancy, education, pregnancy, and motherhood. She is also like those powerful abbesses who provided refuge in convents to wronged wives and negotiated between them and their husbands, who collected and created artworks, and corresponded with powerful men in church and state. ${ }^{23}$

In all of Shakespeare's other plays that deal with the theme of the wronged wife, the woman looks to her male kin for rescue-Desdemona to Lodovico, Imogen to her brothers, Hero, through her cousin Beatrice, to Benedick. ${ }^{24}$ This lack of power was a continuing historical reality for most women. However, the sites where women do intervene effectively to save women from male violence are the saints' legends, and many of these legends have a historical basis. While women in Greek myth have to turn into trees or birds to avoid rape, women in Catholic legend do better, with the help of female saints. Thus, St. Frideswide, pursued by a prospective husband, appeals to St. Catherine, who promptly strikes him blind, thus freeing her devotee to establish a monastery which is believed to have later developed into Oxford University. Many legends were less dependent on miracle and more on the material reality of convents that frequently provided shelter to abused and abandoned wives. Several female saints had begun their religious lives in this fashion-as divorced or widowed women. Paulina, who provides Hermione with a sanctuary away from men, 
represents an updated version of older myth and history, and also a futuristic vision based on that lost past. It is significant that another of Hermione's loyal women, who helps Paulina, is named Emilia, recalling the woman who died for Desdemona as Paulina lives for Hermione. Patience, Queen Katherine's serving woman, echoes Hermione's personification of that "Patience" which will make tyranny tremble.

Paulina is castigated by Leontes in terms very familiar to Shakespeare's audience. When he threatens her with burning, her reply is double-edged:

\section{I care not:}

It is an heretic that makes the fire,

Not she which burns in't.

(II.iii.114-6)

The syntax allows this to mean that the fire is justified when the victim is actually a heretic; it can also mean that the one who makes the fire is actually a heretic, not the one who burns in it. Leontes repeatedly accuses Paulina of witchcraft, an accusation commonly leveled against recusants. Accepting her status as rebel, Paulina demands to know what wheels, racks, fires, flaying, or boiling in leads or oils Leontes has for her. This list of what she calls "old or newer torture"(III.ii.177) recalls not only the tortures inflicted on heretics on both sides of the divide, but also the saints' stories. Saints were often depicted in paintings and statues with the instruments of their torture. These instruments helped identify them-for instance, two saints very popular in England, St. Katherine and St. Barbara, appeared with a wheel and a tower respectively. Women saints' legends usually involved torture and death at the hands of tyrannical kings. Frequently, the tyrants were said to have been converted by the spectacle of the saints' courage, patience, and faith.

Leontes' life exemplifies that idea of a converted tyrant undergoing penance and receiving absolution and the reward of grace. In the Protestant view, merit counted for little, since the Christian could be justified only through faith or gratuitously given grace. Martin Luther was convinced that the idea of satisfaction for sin was unbiblical and that "all forms of penitential or compensatory behaviour were to be identified with the 'works' St. Paul had disparaged." ${ }^{25}$ However, in The Winter's Tale, penitence and voluntarily undertaken suffering or penance are crucial to salvation. After Leontes' conversion, Paulina takes the place of his confessor, which Camillo had occupied earlier. Leontes had specifically described Camillo in these terms: 
I have trusted thee, Camillo,

With all the nearest things to my heart, as well

My chamber-counsels, wherein, priest-like, thou

Hast cleans'd my bosom: I from thee departed

Thy penitent reform'd.

As Leontes' new confessor, Paulina tells him that no amount of prayer and fasting will serve as adequate penance, but he resolves to spend his life commemorating the dead. ${ }^{26}$ After sixteen years, when his lords deplore his refusal to remarry and his persistence in remembering the dead, and even Cleomenes, who brought the oracle, tells him to forget the past: "forget your evil ... forgive yourself" (V.i.5-6), Leontes refuses, unlike Henry, who was only too ready to forget the dead.

Here, the dramatist significantly selects those elements of the Christian life (fasting, praying, and celibacy) that were supposed to be the special province of widows and suggests that they should be practiced by both sexes. There is an element here of pro-women Utopian fantasy-Leontes becomes the ideal man who is willing to do "unmanly" things-be guided by a woman, live a celibate life, and risk dying without an heir. ${ }^{27}$

Given that the Church is normally figured as female (the pope and the Roman Church were attacked as the whoring female, the Scarlet Woman), Leontes' self-subordination to Paulina, whose name and actions identify her with the Church that would reunite man with wife, is the obverse of Henry VIII's divorce of his wife and assumption of headship over the Church. Henry's 1531 reply to Bishop Tunstal's protest against his assuming the title of supreme head of the Church explicitly used the female metaphor, arguing that although the Church was his mother and he her son, he as prince was her head in another sense.

When Leontes' lords insist that he should remarry because an heir is needed, Paulina argues that this Henry VIII-like anxiety for a male heir is unnecessary:

Care not for issue,

The crown will find an heir. Great Alexander

Left his to th' worthiest; so his successor

Was like to be the best.

(V.i.46-9)

That this is a compliment to King James, like the more explicit compliment at the end of Henry VIII, has often been remarked. It suggests that 
Elizabeth's policy was wiser than her father's. More important, it indicates that remembering the past is of greater value than being anxious about the future. To be true to one's past is human; to worry about the future, which in any case is uncertain, is to play God as did Henry VIII, an enterprise doomed to failure. "Issue" is a word often repeated in this play. Hermione preserves herself to "see the issue," but seeing is different from controlling. "Care not for issue," a rephrasing of " $t$ ] ake no thought for the morrow," refutes the favorite argument of the proponents of marriage in the marriage versus celibacy debate-what would become of the world if all were to choose to remain celibate? The Puritan work ethic cares only for issue, in the sense of material results, whether wealth or offspring. Conversely, Paulina advocates spiritual poverty, finding through loss, living by faith and by memory.

The play then proceeds to replace the vision of a biological father-son lineage with other sorts of lineage. Perdita is represented as her mother's daughter, and Florizel as the heir to the two kings whose youthful romantic attachment Leontes recalls when he notes Florizel's resemblance to his father. If Florizel and Perdita remind Leontes of his two lost children, they could equally remind him of his two lost loves, Hermione and Polixenes, whom they so strongly resemble. ${ }^{28}$ The ambiguity in Leontes' speech

O! alas,

I lost a couple, that 'twixt heaven and earth

Might thus have stood, begetting wonder

(V.i.131-3)

is immediately followed up by his mourning the loss of Polixenes' love. Hermione will later say that she preserved her life in the hope of seeing Perdita; Leontes, who has no hope of seeing Hermione, explicitly says that he lives in the hope of seeing Polixenes:

and then I lost

(All mine own folly) the society,

Amity too, of your brave father, whom

(Though bearing misery) I desire my life

Once more to look on him.

(V.i.134-8)

Perdita's name and her life focus the theme of finding that which was lost. It is significant that the heroines of two other late plays have names 
which refer to the Virgin Mary's titles-Miranda ("admired") was constantly applied to her in Latin tags such as "Res miranda"; and Marina suggests "the Star of the Sea." 29 The parable of the prodigal son where the father rejoices over his son who was lost but is now found does not quite fit Perdita's case because here it is the father, not the child, who sinned. And this child was deliberately abandoned, not unwillingly lost. "Loss," then, signifies the recognition of worth after a deliberate discarding.

The particular loss resonates too with a larger loss-a whole society's loss of powerful female presence. If Hermione was "not to be equall'd" (V.i.101), Perdita is described in terms that irresistibly recall celebrations of Mary, and that are also charged with sublimated erotic emotion:

This is a creature,

Would she begin a sect, might quench the zeal

Of all professors else, make proselytes

Of who she but bid follow ...

Women will love her, that she is a woman

More worth than any man; men, that she is

The rarest of all women.

(V.i.106-12)

From this point on, language and spectacle work together to suggest reconciliation on a grand scale, the kind of reconciliation that J. J. Scarisbrick argues occurred in Elizabethan Anglicanism which incorporated many elements of traditional religion, thus maintaining a safe distance from Puritan extremism. ${ }^{30}$ The text reaches forward yearningly to the restoration of lost female presence. I am not arguing, as Barber does, that this yearning is for a biological mother figure removed from the male child, but rather that it is for a virgin goddess figure who could culturally empower the desire, whether felt by men or women, for alternatives to marriage and parenthood.

Hermione as statue appears in a "chapel" and she herself has lived in Paulina's "removed house" with other statues. Her preservation and revelation as a statue after sixteen years suggests the way many parishioners who bought images, vestments, and other church property auctioned under Henry and Edward VI, preserved and restored them to churches in Mary Tudor's reign. ${ }^{31}$ The process was repeated under Elizabeth; despite strict orders to deface and destroy all images, altars, and pictures, especially those of the Assumption of the Virgin, "and all other superstitious and dangerous monuments," ${ }^{32}$ and the imposition of severe penalties for their preservation, many recusants did preserve these objects and some were discovered as late as the nineteenth century. 
Women, especially elderly matrons and single women, "played a conspicuous part in sustaining recusancy." From a list of 157 recusants in 1577 , 91 were women; from 820 indicted circa 1615, 532 were women, of whom 211 were spinsters. Some of the women were formidable matrons such as Margaret Clitherow and Mrs. Wiseman, possible models for Paulina. Mrs. Wiseman was condemned to death by crushing in 1594 (the punishment suffered by Margaret Clitherow) but was eventually reprieved. ${ }^{33}$

In the closing scenes occur a number of words which stress the notvery-hidden subtext. Paulina praises the statue as excelling whatever the "hand of man hath done" (V.iii.17) (the use of the gendered term "man" here is not, I think, fortuitous); both Hermione and Perdita are termed "peerless"(V.iii.14; V.i.94). In the famous English carol "I sing of a maiden" Mary is called "makeless," that is, without an equal. ${ }^{34}$ Leontes praises the statue as bringing the original to remembrance. These are the terms in which images were justified in the debate over idolatry, Catholics insisting that they served to recall the original and to give joy to the worshipers.

Very significantly, the worshipers here are not only men but also or even primarily a woman, a younger woman. Perdita kneels to the statue and says

And give me leave

And do not say 'tis superstition, that

I kneel, and then implore her blessing.

(V.iii.42-4)

The word "superstition" had been highly charged for over half a century. ${ }^{35}$ It was the word invariably used to connote Catholic attachment to images, relics, and cults, whether cults of the saints or the cult of the dead, all condemned as idolatrous. Leontes follows Perdita's lead and wishes to kiss the statue. Traditional devotional practices of kneeling to statues and kissing them had been expressly forbidden from Henry's time onward, although many people continued surreptitiously to perform these actions. All images to which people were in the habit of kneeling, lighting candles, and otherwise performing devotion such as kissing and asking blessing, were ordered to be destroyed because their presence encouraged superstition. ${ }^{36}$ Statues reported to come alive and perform miracles were the targets of special mockery. ${ }^{37}$ Numerous legends of Mary and the saints had statues coming alive and speaking to devotees or performing miracles on their behalf. These visions and apparitions of Mary to the poor and innocent, usually children and young girls, continued to be reported over the centuries well into the nineteenth century. ${ }^{38}$ 
Protestant attacks took two forms. Sometimes these visions were condemned as fraud practiced on the simple-minded by crafty priests who had placed contraptions inside the images to roll the eyes, raise the hands, and so on. Another line of attack was to argue that the visions actually occurred but were caused not by divine but by demonic powers. In this way, Catholicism was connected with witchcraft and condemned for its pagan links, hence Paulina's repeatedly expressed fears that she will be accused of "wicked powers." Even when reassured by Leontes, she asks those to leave who think her magic unlawful:

It is requir'd

You do awake your faith. Then, all stand still.

On; those that think it is unlawful business

I am about, let them depart.

(V.iii.94-7)

Her call to Hermione to "awake" recalls Christ's words to Jairus's daughter. That a woman speaks them and plays the role of raising the dead recalls many stories of saints' miracles-the only stories where women undertake such action. The words also reverberate with double meaning-it is a sleeping or buried faith that would require awaking. For an audience from whom the dramatist carefully conceals the secret of Hermione's being alive, the last scene, protected by the veneer of its pagan setting, would resonate with the miracle plays, based on saints' lives, of a half-century earlier, many of which had been destroyed and thus lost to posterity. Even after the naturalistic explanation for Hermione's survival is provided, the spectacle of miraculous female power, channeled through the triangular fictive kinship of Paulina, Hermione, and Perdita, remains the most compelling symbol.

Fictive kinship, between godparents and godchildren, as between devotees and their name saints, was another element of the old religion that was under attack. ${ }^{39}$ Fictive kinship is crucial to the happy ending that Shakespeare, departing from the sources, gives to The Winter's Tale. The institution of godparenthood, though much watered down in the course of the Reformation, did not disappear from England. The reunion scene, described by the clown, emphasizes the joyful confusion of kinship when Perdita's father meets her adopted father and brother: "the King's son took me by the hand, and call'd me brother; and then the two kings call'd my father brother; and then the Prince, my brother, and the Princess, my sister, call'd my father father; and so we wept" (V.ii.140-4). 
Traditionally, the nobility often chose poor and humble people to be their children's godparents, a practice advocated by More as proper to Christian humility and recognition of kinship with the poor. ${ }^{40}$

Henry VIII does not allow for as extreme a utopian vision as The Winter's Tale, because the facts of history were given, and being relatively recent, were also fairly well known. ${ }^{41}$ Arthur Colby Sprague ascribes the steady stage popularity of Henry VIII to audiences' familiarity with Henry VIII's domestic life..$^{42}$ It is perhaps not fortuitous that this play is the only one of Shakespeare's histories that has the word "famous" in its title: The Famous History of the Life of King Henry the Eighth. However, the fact that Katherine's divorce was perhaps the best-known divorce in recent history allowed it to become a site for debating the question of injustice in conjugal relations. It allowed the dramatist to distinguish between fact and truth-he alters the impact of facts by such devices as the condensation of time in order to stress how one strong and sonless queen, Elizabeth, followed another, Katherine, despite the efforts of the king to ensure patrilineal succession through the subordination of wives and daughters to husbands and fathers.

Graham Holderness has argued that Elizabethan playwrights were in a position to construct versions of recent English history that depended as much on popular memory and perception as on the chronicles, and that could thus depart significantly from the latter. ${ }^{43}$ The phrase "our chosen truth" and the references to "[o]ur own brains" and "the opinion that we bring" hint that the poet and players are about to "make ... true" what they present:

For, gentle hearers, know,

To rank our chosen truth with such a show

As fool and fight is, beside forfeiting

Our own brains and the opinion that we bring

To make that only true we now intend,

Will leave us never an understanding friend.

(Prologue.17-22)

The epilogue indicates the aim of this process:

All the expected good w' are like to hear

For this play at this time, is only in

The merciful construction of good women,

For such a one we show'd 'em. 
That the "one" good woman is Katherine is suggested by her dying wish for a historian who will do her justice, a wish invented and fulfilled by Shakespeare:

After my death I wish no other herald, No other speaker of my living actions

To keep mine honor from corruption,

But such an honest chronicler as Griffith.

(IV.ii.69-72)

Shakespeare's honesty as chronicler is premised on his willingness to construct women mercifully. "The best men," the epilogue says, are those who will follow women's lead in accepting this version of history:

If they smile,

And say 'twill do, I know within a while

All the best men are ours.

(Epilogue.11-3)

The addition of the epithet "best" to "men" is a significant departure from the tenor of other such epilogic appeals, for instance, that in As You Like It, for the suggestion here is that while the "best men" will, sooner or later, follow women in approving the play's construction of women, the lessthan-best men may think otherwise!

Women's history, Shakespeare often suggests, is unwritten, because women's suffering is in excess of what can be said about it. Viola's famous reply to the Duke's question "And what's her history" encapsulates this excess, this inexpressibility: "A blank, my lord" (II.iv.110). Comedy, conventionally the space of women, fools, slaves, and others who are marginal in the "tragical histories" of men, is defined in the induction to The Taming of the Shrew, when Sly asks: "Is not a / comonty a Christmas gambold, or a tumbling-trick?" and receives the reply: "It is a kind of history" (Induction.ii.137-8, 141). Henry VIII too, is "a kind of history"-its generic status has always seemed dubious. ${ }^{45}$ In this uncertain space, Shakespeare unfolds the footnotes that contain the tragic history of Henry's Catholic queen, silenced-but not completely—by her husband's redefinition of marriage, of monarchy, and of religion.

Excess of one kind can be conveyed and countered by excess of another kind. Although Elizabeth was dead when it was produced, Henry VIII is still a daring play in its exposure of Henry and its sympathetic portrayal of 
Katherine. ${ }^{46}$ The similarity of Hermione's trial speech to Katherine's has often been noticed. Hermione declares:

\section{You, my lord, best know}

([Who] least will seem to do so) my past life

Hath been as continent, as chaste, as true,

As I am now unhappy; which is more

Than history can pattern, though devis'd

And play'd to take spectators.

If women's lives contain "more [t]han history can pattern," figures for these lives, as also for a vision of women's survival, have to be drawn from elsewhere. The plays draw on Mariological myth to figure that "more." If Hermione has suffered "more" than is written in history, Perdita is a woman "more worth than any man." Theater had become the space where ritual and spectacle could still evoke memories of the past, a sense of ancestry. Moving across time and space, theater could remind spectators that the oppressive presence of official history was (a) not the only version, and (b) not necessarily the version that would last. Time, in The Winter's Tale, presents a different account of history from that in the prologue and epilogue to Henry VIII. History, with its illusion of fixity, its chronicle of dates and events, makes the spectators weep. Time reminds the spectators that just as the past and its laws and customs, which once seemed immutable, proved transient, so too will the "glistering" (usually a negative word in Shakespeare) present:

$$
\text { it is in my pow'r }
$$

To o'erthrow law, and in one self-born hour

To plant and o'erwhelm custom. Let me pass

The same I am, ere ancient'st order was,

Or what is now receiv'd. I witness to

The times that brought them in; so shall I do

To th' freshest things now reigning, and make stale

The glistering of this present, as my tale

Now seems to it.

(IV.i.7-15)

This is not a flattering or comforting message for those in power.

In this context, the prologue to the play acquires an ironic ring. The prologue promises a sad play "full of state and woe" (line 3 ) that may make 
some spectators, those capable of pity, weep. Not triumph or the Tudor myth but grief and pain are stressed:

Those that can pity, here

May (if they think it well) let fall a tear;

The subject will deserve it. Such as give

Their money out of hope they may believe,

May here find truth too.

(Prologue.5-9)

Given Shakespeare's departures from his sources and valorization of much that was not valorized in official history, the tentative "[m]ay here find truth too" and the play's alternative title "All is True" suggest that truth is not fixed but may be found by sympathetic spectators where they choose to find it. The last lines of the prologue again refer to weeping:

then, in a moment, see

How soon this mightiness meets misery;

And if you can be merry then, I'll say

A man may weep upon his wedding-day.

(Prologue.29-32)

While men do not conventionally weep on their wedding days, women do; and while, as the audience well knew, Henry had no reason to weep on his wedding days, his wives had good reason to weep on theirs. ${ }^{47}$

Although Katherine was a queen, at the level of history as fable, she is also Everywoman, as Henry is Everyman. As G. Wilson Knight puts it, "[h]er every phrase comes direct from her woman's soul, her typical woman's plight. She is universalized, not by abstraction, but rather by an exact realization of a particular person only lately dead." ${ }^{48}$ The epilogue stresses this commonness-women in the audience are "good women" and Katherine is also "such a one" (lines 10-1). ${ }^{49}$

Although a queen, Katherine, like most women, is distanced from her natal kin by marriage. This distancing, central to her powerlessness, speaks to the predicament of all women in societies where the wife moves out of her father's and into her husband's home, but was heightened in the context of royalty where brides were usually pawns in the game of European politics, as was that other Katherine, Henry V's French wife. The formidable presence of Queen Katherine ensures that the audience off stage, like the audience on-stage, cannot forget that although Henry may have in some ways enhanced England's prestige, this prestige was built on hypocritical and ruthless persecution: 
Would I had never trod this English earth,

Or felt the flatteries that grow upon it!

Ye have angels' faces, but heaven knows your hearts.

What will become of me now, wretched lady?

Shipwrack'd upon a kingdom, where no pity,

No friends, no hope, no kindred weep for me,

Almost no grave allow'd me.

(III.i.143-51)

The second element in Katherine's divorce is her unqueening. If the uncrowning of a king is the emotionally charged center of such plays as Richard II and King Lear, the forcible unqueening of Katherine, to which she never acquiesces, not even on her deathbed, points to the dubious status of queen as consort. When Katherine, on her first entry, kneels to her husband to plead the people's cause, and he graciously accedes to her request, the visual impact of a crowned queen kneeling irresistibly recalls the Virgin Mary, represented in paintings and statuary, as mediatrix, kneeling to plead for sinners. ${ }^{50}$ Representations of her holding back her son's wrathful arm, weighing down St. Michael's scales in favor of the sinner, and kneeling before Christ or God, at the head of a flock of sinners, often including the donor and family, were among the most familiar icons. ${ }^{51}$ In such representations, Mary is almost always crowned, since it is her power as Queen of Heaven which enables her to intervene successfully. Significantly, female saints such as Saint Katherine were also believed to play such a role.

The crucial difference between Katherine's queenship and Mary's is that Katherine is queen as wife, while Mary is queen as daughter and as mother. Her paradoxical dual status as mother of her father and sister of her spouse makes her undivorceable. Both Katherine and Hermione appeal from their status as queen-consorts to their irreversible status as daughters. Hermione calls herself "a great king's daughter" (III.ii.39); that her father was the emperor of Russia (Shakespeare's addition to the source) is interesting since Russia was the bastion of a Christian orthodoxy untouched by Protestantism. Katherine's last words attempt a redefining of her status: "Although unqueen'd, yet like / A queen, and daughter to a king, inter me" (IV.ii.171-2).

The status of queen-consort is tenuous because it is linked to her ability to produce a male child that survives. Hermione's daughter, like Queen Katherine's, is condemned as a bastard. In both cases, sons, who are cherished by their fathers, die young. The crux of the matter here is the dependence 
of a woman's status on that of her son. Protestants were willing to honor Mary as mother of Christ but objected to the tendency of popular devotion and of Mariology to exalt Mary in her own right, as immaculately conceived in the mind of the Creator even before the universe came into being. This tendency was also viewed with ambivalence by Roman Catholic authorities who insisted that Mary was subordinate to her son. At issue was the popular need for a goddess and, implicitly, the question of whether woman was to be honored only as mother or in her own right.

Henry VIII and The Winter's Tale are so structured as to move female figures out of the conjugal unit into a community of women and supportive men or into patterns of fictive female kinship. The dramatic action follows Queen Katherine out of her relations with her faithless husband into her own space, where she continues to command honor and where she is glorified for the audience through a number of stage devices. Queen Katherine's last speech is addressed to women:

Nay, Patience,

You must not leave me yet. I must to bed,

Call in more women.

Although unqueen'd, yet like

A queen, and daughter to a king, inter me.

(IV.ii.165-72)

Act IV closes on this note, and act V focuses on Elizabeth, who is queen as daughter, not as wife. The action is so constructed, via condensation of time and alterations in chronological sequence of events, as to replace Katherine with Elizabeth center stage.

The under-dramatization of Anne has been read variously as evidence of Shakespeare's patriarchal bias, as compelled by his fear of censorship, and as necessary in order to focus sympathy on Katherine. ${ }^{22}$ Most commentators betray an inclination to read Katherine and Anne as contrasted figures, saint versus sinner or rebel versus romantic sex object. ${ }^{53}$ In history, as Shakespeare's audience well knew, the fates of Katherine and Anne were more similar than different. As historical fact, marriage was death for Henry's wives; as metaphor, marriage entails a kind of death for many women in the comedies, silenced with kisses or tamed into submission. As Petruchio suggests, marriage "is a way to kill a wife with kindness" (IV.i.208). The only way out of this no-win situation was that chosen by Henry's daughter, who refused marriage and triumphed through that refusal..$^{54}$ 
The celebration of Elizabeth's life and death in the closing scene emphasizes her virginity. If Elizabeth, phoenixlike, creates an heir without giving birth to one, the construction of the play suggests that Elizabeth's triumph following Katherine's misery is also a kind of restoration. Kim H. Noling argues that the play betrays a patriarchal bias because Elizabeth serves only as an interval between two male kings. ${ }^{55}$ I would argue that while Shakespeare could not undo this historical fact, the action and imagery of the play compresses Henry's, Edward's, and Mary Tudor's reigns into a kind of interval between two powerful women, Katherine and Elizabeth, whose legitimacy, as wife and daughter respectively, had been cast into doubt.

The play draws on Mariolatric imagery, the most powerful imagery available in Christian culture for the celebration of the human and the divine as woman, to accomplish this link. The three great pageants toward the close of the play, constructed like paintings in their silence, irresistibly recall three scenes which would be familiar to the audience from Church iconography: the Coronation or mystical marriage of Mary, the Assumption, and the Presentation of the Virgin. ${ }^{56}$ The chronological shifts herethe presentation succeeding rather than preceding the Assumption and Coronation-place all three moments in eternally timeless time, stressing their cyclical nature. One queen may be persecuted and dethroned, but others will succeed; powerful women will not disappear from the face of the earth. I am not arguing here for a static equivalence, but for a wealth of resonance, an appeal to the collective visual memory of the audience..$^{57}$

Noling reads Anne's description of herself as a "handmaid" (with the implicit reference to Mary as the handmaid of the Lord) as a patriarchal gesture, with Henry being the "Father" and Anne the "vessel" of his will. But given that, first, Anne produces a female child whose virginity the play celebrates; second, that Anne is the name of the Virgin Mary's mother; and, third, that Mary's child was not her earthly husband's but was "god's gift," as Elizabeth is called, and was suspected of illegitimacy by Joseph as was Elizabeth by her father, surely Henry, with his disappointed hopes for a son, is pushed altogether into the margins of this symbolic narrative.

Katherine's deathbed vision is entirely the invention of the dramatist. In this vision, enacted on stage and then described by Katherine to her servants, she is encircled by personages clothed in white and gold who repeatedly hold a garland over her head. This image of coronation at death derives from what Warner describes as "one of western Christendom's favourite themes," Mary's coronation as Queen of Heaven after her death: "It switched the moment of Mary's triumph from the Incarnation to the Assumption." ${ }^{58}$ The idea of the Assumption of Mary was originated by a 
woman, Elizabeth of Schonau, and came under very special attack during the Reformation. It was the subject of whole plays in the Corpus Christi cycles. These plays were excised from the York cycle in the early 1560s, and other cycles were similarly censored. In 1576 the northern ecclesiastic commissioners had ordered with respect to the Wakefield plays that "no pageant be used or set furthe ... which tende to the maintenaunce of superstition and idolatrie." 59

Shakespeare's pageant gets around such bans by focusing not on Mary but on a Catholic queen, in a play presented to the son of another persecuted Catholic queen. Images of the Assumption were under particular attack in Protestant England. These images focus on Mary as an old woman, a powerful goddess figure. They generally show her encircled by angels and apostles, while a garland or coronet is held over her head by Christ, God, or both. Famous examples are Titian's 1518 "Assumption of the Virgin" and Velasquez's "Coronation of the Virgin," but there were hundreds of representations in church statuary, prayer books, and stained glass. ${ }^{60} \mathrm{In}$ some of these paintings, such as Titian's, Mary holds up her hands. Shakespeare's Katherine "holdeth up her hands to heaven" and makes "signs of rejoicing" while the six "personages" make "reverend curtsies" to her. Queen Katherine describes the "blessed troop" as casting "thousand beams upon me, like the sun" (IV.ii. s.d., lines 87, 89). This radiating effect is found in paintings of the Assumption. Warner points out the significance of the sun image in Mary-worship: "the key Mariological text in the mass for the Assumption is the vision of the Apocalypse, of 'a great wonder in heaven; a woman clothed with the sun ...' (Revelation 12:1)." ${ }^{61}$

At the moment of her greatest despair, when rejected by Henry, Katherine describes herself as "Like the lily / That once was mistress of the field, and flourish'd"(III.i.151-2). She says she will hang her head and die, but the image of the lily is resurrected in the concluding description of Elizabeth as "A most unspotted lily" (V.iv.61). The lily was "consecrated ... to the Virgin Mary. It was her flower as Queen of Heaven." ${ }^{22}$ She herself was termed a "lily among thorns"-this became one of the most conventional epithets to describe her. In paintings of the Annunciation, a flowering lily almost always appears in the angel's hand or in Mary's chamber. It frequently appears in representations of other scenes of her life too, and the image would inevitably recall her. The variety of lily named the Annunciation or the Madonna lily, was associated with purity in antiquity, and "contrasted with the rose of Aphrodite." 33

Thomas Cranmer's paean to Elizabeth also echoes traditional celebrations of the Virgin. The placing of this paean in the mouth of Cranmer would defuse any audience disapproval of a Mariological subtext. ${ }^{64}$ The anomalous 
celebration of a girl child's birth would inevitably recall that model, for lives of the Virgin, and, following them, lives of the female saints such as the apocryphal Catherine of Alexandria, queen of Egypt, celebrated the girl child's beauty, wisdom, and saintliness. Lives of Mary described in detail her birth, baptism, and presentation at the Temple.

The chief virtue ascribed to Elizabeth by Cranmer is "wisdom" and this wisdom is explicitly connected with the queen of Sheba, and thus with Solomon, to whose reign there is a direct allusion: "[a]nd Judah and Israel dwelt safely, every man under his vine and his fig tree"(1 Kings 4:25). This cluster of images recalls the powerful female figure of Wisdom in the Book of Proverbs, whose praises were traditionally incorporated into the praises of Mary. Not only did Mary-worship "associate the Virgin with Wisdom" but the beauty of the Shulamite of the Song of Songs was also assimilated to the mystical marriage of Mary, as the Church, with Christ: "Thou art all fair, my love; there is no spot in thee" (Sg. 4:7). ${ }^{65}$ After his flattering prophecy of James's reign, Cranmer reverts to his panegyric of Elizabeth and closes it with a description of her as "a most unspotted lily" (emphasis mine).

If these plays, especially Henry VIII, are directed to a royal patron, they are also simultaneously directed to the general audience, especially to women in that audience, who may remember history somewhat differently from the way the king may. Louis Adrian Montrose has suggested that "[i]n the society in which Shakespeare lived, wrote, and acted, the practical effect of performing his plays may have been to encourage the expansion and evaluation of options ... Plays are provocations to thought and patterns for action." ${ }^{66}$ Elizabeth's historical resolution of her predicament as a woman may be dramatized here as a pattern for action for women in the audience. Her obdurate refusal to exchange her status of queen-asdaughter for queen-as-wife is constructed as a myth of female empowerment that answers the disempowering of disobedient Eve/Vashti/Anne and the unqueening of obedient Katherine.

\section{NOTES}

${ }^{1}$ Many feminist critics have elaborated the matrilineal emphases of The Winter's Tale, usually in relation to biological mother-daughter relations and heterosexual fertility imagery. See, for instance, Carol Thomas Neely, Broken Nuptials in Shakespeare's Plays (New Haven and London: Yale Univ. Press, 1985), pp. 191-209. Medieval and Catholic resonances in both plays have been discussed at length by Christian critics, but usually from a Christological rather than a dominantly Mariological perspective. For a summary, see Shakespeare's Christian Dimension: An Anthology of Commentary, ed. Roy Battenhouse (Bloomington and Indianapolis: Indiana Univ. Press, 1994), especially M. D. H. Parker, "Nature and Grace in the Romances." Henry VIII is not among the plays considered. C. L. Barber, who undertook, from a psychoanalytic point of view, a sus- 
tained analysis of connections between the lost Catholic past and Shakespeare's plays, stresses the male perspective, that is, the male search for reunion with the mother, wife, and daughter. See C. L. Barber and Richard P. Wheeler, The Whole Journey: Shakespeare's Power of Development (Berkeley: Univ. of California Press, 1986); and Barber, "Thou that Beget'st Him that Did Thee Beget': Transformation in Pericles and The Winter's Tale," ShS 22 (1969): 59-67.

${ }^{2}$ Marina Warner, Alone of All Her Sex: The Myth and the Cult of the Virgin Mary (New York: Knopf, 1976). Another kind of feminist approach valorizes her biological motherhood. See, for example, Julia Kristeva, "Stabat Mater," in The Female Body in Western Culture: Contemporary Perspectives, ed. Susan Rubin Suleiman (Cambridge MA: Harvard Univ. Press, 1986), pp. 99-118; and Teresa de Lauretis's well-argued critique of Kristeva's "homophobic, heterosexist subtext," in The Practice of Love: Lesbian Sexuality and Perverse Desire (Bloomington and Indianapolis: Indiana Univ. Press, 1994), pp. 163-202, 178. An excellent early history of Mariological symbolism in Western culture is Hilda Graef, Mary: A History of Doctrine and Devotion, 2 vols. (New York: Sheed and Ward, 1963), on which Jaroslav Pelikan draws heavily in his recent reconsideration, Mary through the Centuries: Her Place in the History of Culture (New Haven: Yale Univ. Press, 1996).

${ }^{3}$ She is claimed as women's protector by personified Justice. See Christine de Pizan, The Book of the City of Ladies, trans. Earl Jeffrey Richards (New York: Persea Books, 1982), pp. 217-8. De Pizan's focusing on the Virgin as the ultimate answer to misogyny is well within a medieval tradition of debate. For instance, in the poem "The Thrush and the Nightingale," the pro-women nightingale triumphs conclusively over the misogynist thrush, by foregrounding the Virgin. De Pizan constructs virginity as a symbol of women's pride, dignity, and refusal to enter the subordination of marriage, repeatedly using a set formula ("she had so lofty a heart that she did not deign to marry, nor did she desire that any man be at her side" [p. 33]) to characterize women as different as the apocryphal Christian saint Queen Nicaula of Ethiopia, the mythological Amazon queens Synoppe and Penthesilea, and the Roman Camilla.

${ }^{4}$ As Eileen Power puts it, "[i]n this matter the people ran away from the church, which followed panting in their rear; and the medieval Virgin is essentially their creation, a figure of popular folklore even more than a figure of doctrinal devotion" (in Johannes Herolt, Miracles of the Blessed Virgin Mary, trans. C. C. Swinton Bland [London: George Routledge, 1928], pp. ix-xxxv, xviii-xix). The Immaculate Conception was officially proclaimed in 1854, the Assumption in 1950, Queen of Heaven in 1954. While many Church fathers, including St. Anselm, called Mary Coredemptrix, the pope first used this title as late as 1894, and it is still not official doctrine. All were enshrined in medieval devotion, as well as in many of the Church fathers' writings, and were amply envisioned in medieval and Counter-Reformation art. Stephen Benko (The Virgin Goddess: Studies in the Pagan and Christian Roots of Mariology [Leiden: E. J. Brill, 1993]) remarks: "The fact that popular piety developed the ideas of the 'perpetual virginity' and 'immaculate conception' was a positive contribution to the life of the church because it rescued a crucial part of religion which Christianity nearly lost, namely, the feminine aspect of the divine" (pp. 205-6).

${ }^{5}$ One of the earliest to comment on the significance of this phenomenon as an opting-out of heterosexuality was Janice G. Raymond, A Passion for Friends: Toward a Philosophy of Female Affection (Boston: Beacon, 1986), especially pp. 103-8, "External Suppression: The Dissolution and the Protestant Reformation." See Theodora A. Jankowski's analysis of virginity as liberating for many nuns and religious women, in Women in Power in the Early Modern Drama (Urbana: Univ. of Illinois Press, 1992), pp. 25-36; Merry E. Wiesner's account of the "role of women in late medieval Christianity," 
in Women and Gender in Early Modern Europe (Cambridge: Cambridge Univ. Press, 1993), pp. 181-5; and Kathleen Casey, "The Cheshire Cat: Reconstructing the Experience of Medieval Women," in Liberating Women's History: Theoretical and Critical Essays, ed. Berenice A. Carroll (Urbana: Univ. of Illinois Press, 1976), pp. 224-49, who takes a dim view of the effects of the Mary cult for women but acknowledges that many nuns had access to power, learning, and intellectual debate.

${ }^{6}$ The in-many-ways-still-dominant feminist view of critics such as Valerie Wayne who argue that "marriage was, then, the historical response to misogyny in the Renaissance" ("Historical Differences: Misogyny and Othello," in The Matter of Difference: Materialist Feminist Criticism of Shakespeare, ed. Valerie Wayne [New York: Harvester Wheatsheaf, 1991], pp. 153-79, 172), has been challenged by many feminist historians; see Retha M. Warnicke, Women of the English Renaissance and Reformation (Westport CT and London: Greenwood Press, 1983), pp. 83-6, 142-85. I agree with Valerie Traub's argument regarding the heterosexism of much criticism of Renaissance drama, in her essay "Desire and the Differences It Makes," in The Matter of Difference, pp. 81-114. The valorization of marriage as "the" response to misogyny underplays the misogyny structured into marriage and often reads medieval critiques of marriage as critiques of women. But medieval writings advising women against marriage often criticized men equally harshly.

${ }^{7}$ For an extended reading on these lines and a documented elaboration of each of the features mentioned below, as well as others, see my analysis of her presence in visual art and literature as a site for nonheterosexual imaginings, in Sappho and the Virgin Mary: Same-Sex Love and the English Literary Imagination (New York: Columbia Univ. Press, 1996), pp. 5-9, 14-36.

${ }^{8}$ See Herolt for several examples, ranging in tone from the pathetic to the comic.

${ }^{9}$ For several brilliant accounts of, and perspectives on, this lineage, see Interpreting Cultural Symbols: Saint Anne in Late Medieval Society, ed. Kathleen Ashley and Pamela Sheingorn (Athens and London: Univ. of Georgia Press, 1990). Some of the most prominent paintings in the Western canon celebrate this female lineage, for example, Leonardo da Vinci's "The Virgin on the Knees of St. Anne."

${ }^{10} \mathrm{~A}$ common subject of medieval iconography was the female version of the Tree of Jesse, tracing Jesus' family tree backward through Mary and her ancestresses with their consorts.

${ }^{11}$ Examples include David Gerard (1450-1523), "Virgo Inter Virgines (The Virgin amongst Virgins)," where Mary presides over a community of scholarly women saints, several of them dressed as nuns and one as a queen, and musical angels. Mary frequently appears, book in hand, in paintings of male scholars and fathers of the Church, blessing their scholarship.

${ }^{12}$ Barber and Wheeler, p. 1. Ted Hughes, who, in Shakespeare and the Goddess of Complete Being (New York: Farrar Straus Giroux, 1992), traces the roots of Mariology to pagan goddess cults and examines Shakespeare's dramatic patterns in relation to those myths, also focuses on the masculine psyche's attainment of wholeness through acceptance of female presence.

${ }^{13}$ Thus in John Bale's play, The Three Laws of Nature $(1538,1562)$, Sodomy appears dressed as a monk. See Alan Bray, Homosexuality in Renaissance England (London: Gay Men's Press, 1982), p. 19, for references to the papacy as Sodom.

${ }^{14}$ The Colloquies of Erasmus, ed. Edwin Johnson, trans. Nathan Bailey (1524; London: Reeves and Turner, 1878), p. 231.

${ }^{15}$ Samuel Taylor Coleridge considered it "a mere indolence in the bard" not to have provided some explanation for this long concealment (Coleridge's marginalia, quoted in the Signet Classic edition, The Winter's Tale, ed. Frank Kermode [Harmondsworth: Penguin, 1963], p. 181). 
${ }^{16}$ The Riverside Shakespeare, ed. G. Blakemore Evans (Boston: Houghton Mifflin, 1997). Further references to Shakespeare's plays are to this edition and are indicated parenthetically in the text.

${ }^{17}$ See John Bossy, Christianity in the West, 1400-1700 (Oxford and New York: Oxford Univ. Press, 1985); and J. J. Scarisbrick, The Reformation and the English People (Oxford: Blackwell, 1984) for a general overview; for the particular attack on devotion to the Virgin and the female saints, see Eamon Duffy's monumental study, The Stripping of the Altars: Traditional Religion in England, c. 1400-c. 1580 (New Haven and London: Yale Univ. Press, 1992), pp. 155-206, 256-65.

${ }^{18}$ The phrase is Rodney Poisson's in "Death for Adultery: A Note on Othello," SQ28, 1 (Winter 1977): 89-92, 91. The point is also made by most critics of Henry VIII, for instance, Arthur Colby Sprague, Shakespeare's Histories: Plays for the Stage (London: Society for Theatre Research, 1964): "Shakespeare as a boy is likely to have talked with old people who remembered hearing of the birth of the Princess Elizabeth" (p. 150). As Judith H. Anderson (Biographical Truth: The Representation of Historical Persons in TudorStuart Writing [New Haven: Yale Univ. Press, 1984]) says: "Truth-to-life is at once the problem and the fascination of Henry VIII' (p. 130).

${ }^{19}$ See Roy Strong, The Cult of Elizabeth: Elizabethan Portraiture and Pageantry (London: Thames and Hudson, 1977); and Helen Hackett, Virgin Mother, Maiden Queen: Elizabeth I and the Cult of the Virgin Mary (Basingstoke: Macmillan, 1995), for two opposing views on whether or not Elizabeth deliberately fostered the parallel.

20 "Annunciation," in John Donne: The Complete English Poems, ed. Albert J. Smith (Harmondsworth: Penguin, 1971), p. 306.

${ }^{21}$ Philippa Berry, Of Chastity and Power: Elizabethan Literature and the Unmarried Queen (London: Routledge, 1989).

${ }^{22}$ Until feminist criticism recuperated her in the late twentieth century, Paulina was, on the whole, ignored by critics, treated as purely functional, or viewed with guarded distaste as playing a "harpy role" (Bertrand Evans, Shakespeare's Comedies [Oxford: Clarendon, 1960], p. 313).

${ }^{23}$ For a succinct account of sixteenth-and seventeenth-century Englishwomen who acquired education and leadership positions in convents on the Continent, and of the extensive activities of Mary Ward's Institute of the Blessed Virgin Mary, founded 1616, see Marie B. Rowlands, "Recusant Women, 1560-1640," in Women in English Society 1500-1800, ed. Mary Prior (London: Methuen, 1985), pp. 149-80.

${ }^{24}$ Whether the woman survives or dies often depends on the response of male kin. For an analysis of Lodovico's failure to respond adequately as a crucial element in Desdemona's death, see my “'Proper' Men and 'Fallen' Women: the Unprotectedness of Wives in Othello," SEL 34, 2 (Spring 1994): 341-56.

${ }^{25}$ Bossy, p. 92.

${ }^{26}$ Commemoration of the dead was a feature of traditional religion attacked by reformers. See Duffy, pp. 299-368.

${ }^{27}$ The figure suggests the obvious parallel of a crowned king's relation to his widowed mother, the queen dowager (see Scarisbrick, Henry VIII [Berkeley: Univ. of California Press, 1968], pp. 278-9).

${ }^{28}$ Among those who have noted the homoeroticism of the Leontes-Polixenes relationship are J. I. M. Stewart, Character and Motive in Shakespeare: Some Recent Appraisals Examined (London: Longmans, Green, 1949), pp. 30-9; and Barber and Wheeler, pp. 328-30.

${ }^{29}$ The point about Marina's name is made by M. D. H. Parker, The Slave of Life: A Study of Shakespeare and the Idea of Justice (London: Chatto and Windus, 1955), pp. 179-81.

${ }^{30}$ Scarisbrick, Reformation, pp. 185-8. 
${ }^{31}$ Duffy, pp. 569-71. The objects included images, Latin books, and paintings. One Mistress Dutton at Chester had a rood, two pictures, and a mass book. The articles and injunctions produced for the episcopal visitations of 1560 and 1561 show special anxiety about the possible preservation of representations of the Assumption of the Virgin and images of St. Katherine, St. Nicholas, and other saints, among other objects. For details of how people buried altar stones and holy water stoups in gardens, bidding the Lord be with them (the objects), see Scarisbrick, Reformation, chap. 5, "The Spoliation," pp. 85-108.

${ }^{32}$ The Interrogations were produced for the episcopal visitations of 1560 and 1561, quoted in Duffy, p. 571.

${ }^{33}$ Scarisbrick, Reformation, pp. 150-1. See Rowlands for a detailed account.

34 "Makeless" means "unequalled, unparalleled, matchless, peerless" and has a secondary meaning of "without a mate" (Middle English Dictionary, ed. Sherman M. Kuhn and John Reidy [Ann Arbor: Univ. of Michigan Press, 1975], Part M1, 53).

${ }^{35}$ For documentation and analysis of how this word was used, see Duffy, pp. 2, 266-98.

${ }^{36}$ The Injunctions of 1538 condemned kissing of images as "idolatry and superstition" and commanded that such "abused images" be removed (Duffy, p. 407).

${ }^{37}$ For examples of such mockery, see Duffy, pp. 408-10.

${ }^{38}$ For a comprehensive account, see Sandra L. Zimdars-Swartz, Encountering Mary: From La Salette to Medjugorje (Princeton: Princeton Univ. Press, 1991).

${ }^{39}$ For an examination of the roots of this concept in traditional Christianity, and the link between the valorization of celibacy and the idea of all Christians as kin, see Marc Shell, The End of Kinship: "Measure for Measure," Incest, and the Ideal of Universal Siblinghood (Stanford: Stanford Univ. Press, 1988).

${ }^{40}$ Bossy, p. 16.

${ }^{41}$ It does not seem relevant to enter the debate on the authorship of Henry VIII. I assume throughout that Shakespeare is the author, although my argument would not be substantially altered even if the play were coauthored.

${ }^{42}$ Sprague, p. 142.

${ }^{43}$ Graham Holderness, Shakespeare Recycled: The Making of Historical Drama (Hertfordshire: Harvester Wheatsheaf, 1992), especially pp. 15-6. Holderness excludes Henry VIII from his discussion, despite Lee Bliss's argument for the ironic critique of political history in this play, in "The Wheel of Fortune and the Maiden Phoenix of Shakespeare's King Henry the Eighth," ELH 42, 2 (Spring 1975): 1-25.

${ }^{44}$ My overall position with regard to Shakespeare's representation of women follows critics such as Claire McEachern, "Fathering Herself: A Source Study of Shakespeare's Feminism," SQ 39, 3 (Fall 1988): 269-90; and Richard Levin, "Women in the Renaissance Theater Audience," SQ 40, 2 (Summer 1989): 165-74, who places the epilogue in the context of many such appeals by dramatists to women spectators. He persuasively refutes Kathleen McCluskie's argument in "The Patriarchal Bard: Feminist Criticism and Shakespeare: King Lear and Measure for Measure," in Political Shakespeare: New Essays in Cultural Materialism, ed. Jonathan Dollimore and Alan Sinfield (Ithaca: Cornell Univ. Press, 1985), pp. 88-108.

${ }^{45}$ In Shakespearean Structures (London: Macmillan, 1981), Ralph Berry reads fools and women as "the two great sources of critical challenge" to the "largely male cast, usually making a botch of affairs" in every play, and notes that "[i]ntelligence without power" is what fools and women have in common (p. 13). However, I disagree with Berry's reading of Henry VIII in Shakespeare and the Awareness of the Audience (London: Macmillan, 1985), which follows Frances A. Yates, Shakespeare's Last Plays: A New Approach (London: Routledge and Kegan Paul, 1975) in ignoring the epilogue; and Howard Felperin, Shakespearean Romance (Princeton: Princeton Univ. Press, 1972) in reading the play as "glorified propaganda" (p. 209) for the Tudor myth. 
${ }^{46}$ I do not enter here into the ironies the play directs against Henry's plea of "conscience" as these have been well analyzed by F. W. Brownlow, Two Shakespearean Sequences: "Henry VI" to "Richard II" and "Pericles" to "Timon of Athens" (London: Macmillan, 1977); Anderson; and Peter L. Rudnytsky, "Henry VIII and the Deconstruction of History," ShS 43 (1991): 43-57. It is interesting that nineteenth-century critics, under the influence of post-Wollstonecraft Romantic feminism, found in Henry VIII a text to support their views. See William Hazlitt's extended denunciation of Henry as "the most disgusting" of all English kings and his argument that Shakespeare represents him as "monstrous" and "ridiculous" (extracted in King John and Henry VIII: Critical Essays, ed. Frances A. Shirley (New York: Garland, 1988), pp. 287-90, 289, 290.

${ }^{47}$ I use the present tense in the first part of this sentence because in many parts of the world, the tears shed are still more than conventional; in many cultures such as those of north India, women's wedding songs are more like dirges. Katherine Minola is one of the few brides in Shakespeare who weeps copiously on stage on her wedding day.

${ }^{48} \mathrm{G}$. Wilson Knight, The Crown of Life: Essays in the Interpretation of Shakespeare's Final Plays (London: Oxford Univ. Press, 1947), p. 296.

${ }^{49}$ I differ here with Paul Dean ("Dramatic Mode and Historical Vision in Henry VIII," SQ 37, 2 [Summer 1986]: 175-89), who argues that the play distances the audience from the royal protagonists, thus offering the pleasures of voyeurism and eavesdropping.

${ }^{50}$ For the historical Queen Katherine's popularity among the poor, and the persistent tradition which credited her with saving the apprentices of London from hanging for their part in the Ill May Day of 1517, see Garrett Mattingly, Catherine of Aragon (New York: Vintage, 1941), pp. 168-72. Mattingly quotes the ballad, still current half a century later, which says that the queen "lived beloved all her days."

${ }^{51}$ Interestingly, this faith in her merciful intervention persisted into the Anglican church; see Donne's poem "The Virgin Mary":

As her deeds were

Our helps, so are her prayers; nor can she sue

In vain, who hath such titles unto you.

${ }^{52}$ Kim H. Noling, "Grubbing Up the Stock: Dramatizing Queens in Henry VIII," SQ 39, 3 (Fall 1988): 291-306, takes the first view; Marjorie H. Nicolson, "The Authorship of Henry the Eighth," PMLA37,3 (September 1922): 484-502, the second; and Hugh Richmond, "The Feminism of Shakespeare's Henry VIII," ELWIU6, 1 (Spring 1979): 11-20; and Linda McJ. Micheli, "Sit by Us': Visual Imagery and the Two Queens in Henry VIII," SQ 38, 4 (Autumn 1987): 452-66, the third.

${ }^{53}$ See, for example, Rudnytsky, Noling, and Micheli.

${ }^{54}$ Philippa Berry argues for the radical significance of Elizabeth's refusal to marry, thus letting the Tudor line die, and for her being part of a community of women. She also notes that "Elizabeth's unmarried state was in conflict with Protestant ideology ... which had commenced a propaganda campaign on the importance of marriage" (p. 66) and that Elizabeth had never given her official sanction to married clergy.

${ }^{55}$ Noling, p. 303.

${ }^{56}$ If, as Scarisbrick argues, the Reformation had "effected ... a shift from the visual to the aural" (Reformation, p. 163), Shakespeare's last plays move in the reverse direction. Not for nothing was the theater attacked by Puritans in terms very similar to their attacks on Catholicism. A Mirror of Monsters is typical in its description of actors as fiends, apes, hellhounds, vipers, painted sepulchers, and dogs sent by their captain Satan to entice people to the Devil (Marchette Chute, Shakespeare of London [New York: Penguin, 1991], p. 54). Precisely the same kind of abuse was hurled at papists. 
${ }^{57}$ Barbara Hodgdon (The End Crowns All: Closure and Contradiction in Shakespeare's History [Princeton: Princeton Univ. Press, 1991]) uses the word "assumption" in passing to describe Katherine's deathbed scene but does not elaborate its significance (p. 216). The ambivalence might also appeal to King James who by all accounts had a soft spot for Catholicism. I use the term "Mariolatric" as descriptive, not pejorative, as I do not share Christian disapproval of idolatry, and see Mary-worship as linked with worship of goddesses in other cultures.

${ }^{58}$ Warner, p. 113.

${ }^{59}$ Quoted in Duffy, p. 580.

${ }^{60}$ For an English example, see "The Death of the Virgin" and "The Virgin as Queen of Heaven," in the Winchester Psalter, MS. Cotton Nero V.IV. folios 29 and 30, c. 1145-55, British Library, reproduced in Pelikan, pp. 202-3. In the second of these, Mary holds up her hands.

${ }^{61}$ Warner, p. 93.

${ }^{62}$ Esther Singleton, The Shakespeare Garden (New York: W. F. Payson, 1931), p. 164. See Graef 1:112, 154, 157, 184, 194, for the use of this image over the centuries. It is very similar to the image of the lotus, which grows in the mire but is untouched by it, recurrent in Hindu iconography and poetry.

${ }^{63}$ Encyclopaedia Britannica (1967), 14:28.

${ }^{64}$ Richmond sees the play's resolution in the presentation of Cranmer and Elizabeth as respectively "male and female epitomes of the values which Shakespeare sanctions" (p. 18).

${ }^{65}$ Mary's wisdom was more than symbolic in Mariology. She was described as wise and learned, a miraculous child who lived in the Temple from age three. This tradition developed from the second-century Protoevangelium, which describes her as walking at the age of six months and chanting with the angels at birth. Bernardine of Busti in his Mariale (ca. 1478) argues that she was supremely wise and knew all branches of knowledge including rhetoric, logic, physics, and metaphysics. Paintings of her as a child, at the Annunciation and at Pentecost, frequently represent her with a book.

${ }^{66}$ Louis Adrian Montrose, "The Purpose of Playing: Reflections on a Shakespearean Anthropology," Helios 7, 2 (1979-80): 51-74, 67-8. 